" Trade Liberalization and Foreign Direct Investment: An Applied General Equilibrium Model for Costa Rica"

Lisandro Abrego

CSGR Working Paper No. 26/ 99

April 1999
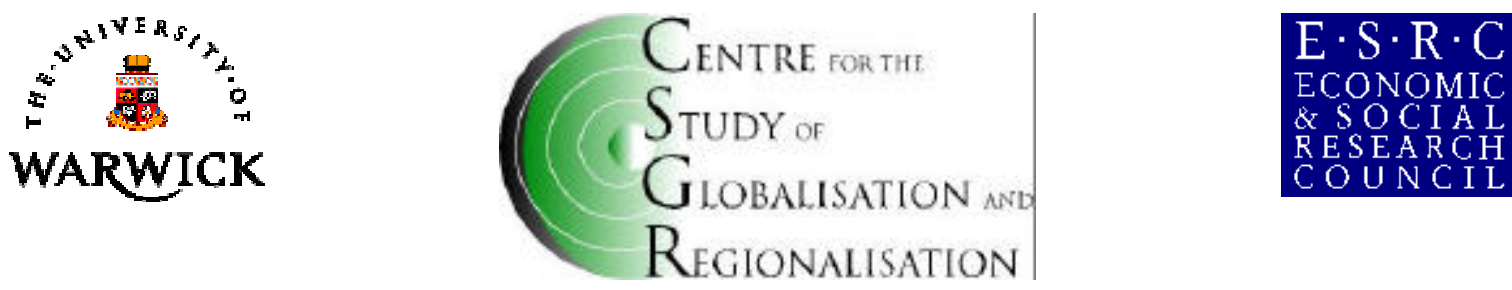

Centre for the Study of G lobalisation and Regionalisation (CSG R), University of Warwick, Coventry CV4 7AL, United-Kingdom. URL: http://www.csgr.org 


\title{
Trade Liberalization and Foreign Direct Investment: An Applied General Equilibrium Model for Costa Rica \\ Lisandro Abrego ${ }^{1}$ \\ CSGR, Univesity of Warwick, \\ CSG R Working Paper No. 26/ 99 \\ April 1999
}

\begin{abstract}
:
This paper quantifies the welfare impact of unilateral trade liberalization and computes the optimal tariff structure for Costa Rica in the presence of trade-policy-induced international capital flows and foreign capital taxation. For this, an applied general equilibrium model integrating trade, capital flows and international capital income taxation is used. The model has been calibrated to a 1990-91 data set for the economies of Costa Rica and a group of OECD countries. In the model, foreign capital income is taxed by host countries and the tax-credit system operates in foreign investors home countries. Results for Costa Rica show that complete trade liberalization ends up being welfare-reducing, as it leads to an outflow of capital and loss of tax revenue which more than offset the efficiency gains from an enhanced resource allocation. The optimal tariff structure for the Costa Rican economy turns out to be a mixture of import tariffs and subsidies, though of a relatively small level.
\end{abstract}

Keywords: Trade Liberalization, Foreign Direct Investment, International Capital Income Taxation, Foreign Tax Credits, Costa Rica.

JEL classification: F13, F21, H20, O54.

Address for correspondence:

Lisandro Abrego

CSGR

University of Warwick,

Coventry CV4 7AL

United Kingdom

Tel.: +44 (1203)524462, Fax: +44 (1203) 523032,

Email: L.E.Abrego@warwick.ac.uk

\footnotetext{
${ }^{1}$ I am grateful to Carlo Perroni and John Whalley for very useful suggestions and comments, and to seminar participants at the University of Warwick. I also thank the Ford Foundation for financial support through the Institute of International Education.
} 


\section{N on-Technical Summary}

It is well-known that, in the absence of foreign capital taxation, international capital inflows induced by the imposition of import tariffs are welfare-reducing for a small open economy-whose optimal trade policy continues to be one of free trade. Less well-known is the fact that when a host, small open economy taxes foreign capital and taxes paid by foreign companies are credited against their corresponding tax liability in their home country, tariffinduced-capital inflows may be welfare-enhancing, and the optimal trade policy for the host economy will not longer consist of free trade. In such a case, therefore, trade liberalization by a small economy may indeed reduce its welfare.

This paper uses a calibrated general equilibrium model to quantify the welfare effect of trade liberalization in the small open economy of Costa Rica once trade-policy-induced international capital flows and foreign capital taxation are taken into consideration. It also computes Costa Rica's optimal tariff structure under this setting. The model used disaggregates economic activity into 10 sectors, and is calibrated to a 1990-91 data set on production, trade, consumption, factor use, and capital income taxation both for Costa Rica and a group of OECD countries. The OECD countries included in this group are those which, as of 1990-91, were using the tax-credit mechanism described above, and accounted for roughly $80 \%$ of Costa Rica's foreign direct investment.

Our results show that, with foreign capital taxation by Costa Rica and the tax credit mechanism in force in the OECD countries included in the model, complete elimination of import-tariffs by Costa Rica would reduce its welfare. The optimal tariff structure for this economy turns out to consist of a combination of relatively low import tariffs and subsidies. Though literally interpreted these results seem to provide a case against free trade, we qualify them by noting that the nature of the model used does not capture neither dynamic gains associated with trade nor other static cost usually linked with non-uniform tariff structures (such as rent-seeking-related costs). 


\section{Introduction}

This paper uses a calibrated general equilibrium model to quantify the welfare effect of trade liberalization and compute the optimal tariff structure in a small economy (Costa Rica) when trade-policy-induced international capital flows and foreign capital taxation are present.

A well-known result from the "tariff-jumping" investment literature of the 1970s is that import-tariff-induced capital inflows will be immiserizing for a small open economy (e.g. Brecher and Diaz-Alejandro, 1977). It is also known that this result relies crucially on the assumption that the host economy does not tax foreign capital (Bhagwati, 1973). As Bond (1991) has shown, if this assumption is lifted and taxes paid in the host country by foreign companies are credited in the source country against the corresponding domestic tax liability, tariff-induced capital inflows are no longer immiserizing. The reason for this is that in this case foreign capital brings with it tax revenue that would otherwise go to the capital-exporting country. Therefore, to capture this revenue and increase national income, it will be optimal for a small economy to impose a tariff on its imports - provided that the importable sector uses capital intensively

The possibility of import tariffs being welfare-enhancing for a small economy may have some policy implications for many developing countries which have embarked on outward-oriented growth strategies in the last fifteen years or so. First, unilateral trade liberalization and foreign direct investment figure prominently in most LDCs' "new" growth strategies. Second, in many developing countries trade liberalization 
has implied a lower tariff protection for the manufacturing sector (relative to others), which tends to be relatively capital-intensive. This, as the Stolper-Samuelson theorem suggests, will tend to reduce the return to capital and thereby FDI inflows to these countries. Third, the bulk of FDI in developing countries originates in developed countries, the majority of which uses the tax credit mechanism when taxing foreign source income. ${ }^{1}$ In this context, unilateral trade liberalization could deteriorate national welfare. Whether it does or not is an empirical question - which would depend on the relative strength of the positive effect of lower distortions resulting from freer trade, and the negative effect associated with the loss of tax revenue and income following lower FDI inflows.

Although a lot of work has been devoted to the theoretical link between import tariffs and international capital flows (see e.g. Wong, 1996), model-based empirical work endogenously linking capital flows to tariff changes in a general equilibrium setting - whether with foreign capital taxation or not - is quite scant. In fact, the only calibrated study that appears to have addressed this linkage is Goulder and Eichengreen (1992). ${ }^{2}$ However, they focused exclusively on portfolio investment, without

\footnotetext{
${ }^{1}$ As of 1991, 15 out of 24 OECD countries offered their companies credits for taxes paid in countries with which a treaty to avoid double taxation was not in effect (see OECD, 1991).

${ }^{2}$ Some applied general equilibrium models seeking to quantify the effects of the North American Free Agreement (NAFTA) explored the likely impact of incorporating FDI flows, but did so in an ad-hoc, exogenous fashion. See Brown (1992); Francois and Shiells (1994). Damus et al. (1991) have studied the implications of the existence of tax credits for Canada but in a corporate tax reform context.
} 
considering FDI. They do not consider international capital income taxation either.

In this paper we quantify the welfare impact of unilateral trade liberalization in a small economy (Costa Rica) once FDI-flow responses are taken into account and taxation of FDI is allowed for. For this, a multisectoral applied general equilibrium model integrating trade, capital flows and international capital income taxation is used. The model has been calibrated to a 1990-91 data for Costa Rica and a group of OECD countries (those using the credit mechanism when taxing foreign source income), and is also used to compute Costa Rica's optimal tariff structure. We show that, with foreign capital taxation and the tax credit system in force, free trade is no longer first-best for the Costa Rican economy. We find that the optimal tariff structure for this economy would consist of a combination of relatively low import tariffs and subsidies.

The paper is organized as follows. The next Section briefly discusses the relationship between import tariffs, capital flows and welfare with and without tax credits. Section 3 describes recent trade liberalization and FDI policy in Costa Rica. Section 4 presents our model, while Section 5 discusses the nature of the data used for its implementation. Section 6 analyses simulation results, and Section 7 summarizes and concludes.

\section{Tariffs, Capital Flows and Welfare}

The relationship between unilateral tariff changes and international capital movements has been analyzed in great detail in the theoretical international trade literature (see, e.g. Mundell, 1957; Jones, 1967; Wong, 1995). The dominant approach 
considers trade and capital movements to be substitutes for each other. ${ }^{3}$ This approach is based on the traditional Heckscher-Ohlin model, in which countries differ in terms of relative factor endowments. As is well known, in this model free trade leads to the equalization of factor prices, which eliminates the rationale for factor movements. Hence free trade is a perfect substitute for factor movements. On the other hand, if factors move from where they are abundant to where they are scarce, the bases for trade are reduced, or disappear. Hence factor movements are a substitute for trade (Ruffin, 1984).

The interaction between tariff changes and capital movements was first formally presented by Mundell (1957). In a two-sector, two-factor model, invoking the StolperSamuelson theorem, Mundell shows that when a tariff is imposed by the laborabundant country the return to capital is increased, and capital moves there; with perfect capital mobility, trade eventually disappears. This type of analysis later gave rise to the literature on "tariff-jumping" investment and its welfare consequences for a small open economy. The main conclusion of this literature was that the combination of capital inflows and distortionary tariff barriers in a small economy would result in immiserizing growth. The idea had been suggested in Johnson (1967) and Bhagwati (1973), and it was further developed by Minabe (1974), and Brecher and Diaz-Alejandro (1977) in a two-good, two-factor framework. It was generalized by Jones (1984), and especially by Neary and Ruane (1988). The second two authors

\footnotetext{
${ }^{3}$ Schmitz and Helmberger (1970), Markusen (1983), and Wong (1986) have presented models in which trade and capital flows are complements.
} 
lifted the restriction on the number of goods and factors, and extended the main result to the case in which capital inflows are entirely endogenous.

In all these models, however, the result of distortionary tariff changes leading to immiserizing capital inflows relies crucially on foreign capital not being taxed by the host country. Bond (1991) presents a general equilibrium model with foreign capital taxation and two goods - one of which is imported - for small economy ("small" both in goods and capital markets). With the importable good being capital-intensive, Bond shows that if the credit mechanism is present in foreign investors' home country, the optimal import tariff for a small, host economy is positive. With the credit mechanisms present in the capital-exporting country, by taxing foreign capital income, the host country extract a gain in terms of tax revenue that would otherwise be captured by the home country, thus increasing national income and welfare. As Bond indicates, by bringing with it tax revenue, foreign capital generates a kind of (positive) fiscal externality in the host country. Therefore, a subsidy on foreign capital is called for, and this can be granted in the form of an import tariff.

The argument, as presented by Bond, runs as follows. For the host to capture all of the tax revenue associated with foreign capital income, its tax rate must be set at a level equal to that in the capital-exporting country. This, however, gives rise to a divergence between private and social cost of capital, i.e. the gross and the net rate of return, respectively. The latter is indeed the return required by foreign capitalists, which in equilibrium must be the same in the host and home country. Therefore, the optimal policy for the host consists of subsidizing foreign capital at a rate equal to the income tax rate. As Bond (p. 321) puts it, "essentially, the home country wants 
to pay the taxes for the owners of imported capital and to impose no distortions in the goods market."

In practice, however, it might not be feasible for a country to subsidize foreign capital in such a direct way. On the other hand, as pointed out by Bond, some capitalexporting countries (such as the USA) do not grant credits for taxes that have actually not been paid. Under these circumstances, it might be easier and more effective for a capital-importing country to resort to an indirect form of subsidization, such as an import tariff-provided, of course, that foreign capital locates in the importcompeting sector. As the tariff will distort consumption decisions, it will be an inferior option to the direct subsidy — but still superior to free trade. In Section 6 we compare the performance of the direct subsidy vis-à-vis that of the optimal tariff.

\section{Recent Trade and Foreign Investment Policy in Costa Rica}

Like the rest of Central American countries, ever since the creation of the Central American Common Market (CACM) in 1960, Costa Rica followed a growth strategy based on industrialization through import substitution, especially of consumer goods. In trade policy terms, this strategy demanded the imposition of high tariff rates for consumer goods, on the one hand, and of low import taxes for intermediates and capital goods, on the other. Tariff protection for import substitutes during this period was thus characterized by a somewhat high average level and dispersion (First column of Table 1).

In the mid-1980s, in the context of broader policy reforms, the strategy of import substitution was partially abandoned, as the country embarked on more open trade 
Table 1: Nominal Import-Tariff Protection in Costa Rica

$(\%)$

$\begin{array}{lrr} & 1987 & 1994 \\ & 4.8 & 6.2 \\ \text { Primary sector } & 59.1 & 15.1 \\ \text { Food. bev. and tob. } & 41.1 & 19.9 \\ \text { Textiles and apparel } & 27.3 & 4.9 \\ \text { Paper and printing } & 12.2 & 5.7 \\ \text { Chemical products } & 23.8 & 9.3 \\ \text { Non-met. mineral prod. } & 23.6 \\ \text { Metal products } & 14.2 & 8.6 \\ \text { Other manufacturing } & 21.7 & 9.3\end{array}$

Source: Calculations based on SIECA (1993) and WTO (1995). 
policies, intending to foster growth mainly through export expansion. Since then, but specially since 1990 - the year that Costa Rica acceded to GATT - all import quantitative restrictions and regulations - except those having to do with security, health and environmental considerations - have been eliminated, while tariff rates have been substantially reduced, especially for consumer goods of industrial origin (Table 1). As a result, both the level of protection and its dispersion have been substantially lowered.

Simultaneously to this unilateral trade liberalization, Costa Rica has also embarked on some reciprocal, regional trade liberalization. In effect, Costa Rica signed a free trade agreement with Mexico in 1994, which went into effect at the beginning of 1995. It has also been engaged in negotiations to establish a free trade area with Colombia and Venezuela, though no formal agreement has been reached. There has also been some further liberalization within the CACM, especially of agricultural goods.

Costa Rica's trade reforms have been accompanied by changes in its foreign investment regime, seeking to make the country more attractive to foreign companies. The idea has been to foster growth not only by reducing distortions but also by increasing capital accumulation. Foreign investment is also supposed to be a response to the need of reducing unemployment and increasing productivity levels; the latter to the extent that FDI can produce some technology transfer benefiting eventually domestic firms as well. Costa Rica's reforms of its FDI regime, however, have not been as far-reaching as those in the area of trade policy. They have consisted mainly of the abolishment of restrictions on international capital movements, and the partial lifting 
of foreign ownership restrictions in some economic activities. However, important foreign ownership restrictions still continue in place in activities such as banking and insurance, telecommunications, and energy (Nathan and Associates, 1994). Foreign investment in newspapers and advertising agencies is prohibited, while regulations in the transport and tourism sectors discriminate against foreign investors and set limits to their participation.

Recent Costa Rican efforts to attract FDI have focused on the subscription of bilateral investment treaties (BITs) with some developed countries. Among other things, these BITs provide national treatment to foreign investors, as well as the option of international arbitration in dispute settlement. They are also consistent with the World Trade Organization's provisions on Trade-Related Investment Measures (TRIMs), which ban the use of performance requirements. As of 1994, Costa Rica had established BITs with Switzerland and Germany, and was in the process of negotiating similar agreements with the United States and Spain. Regional free trade agreements - such as the one subscribed with Mexico in 1994 - are also intended to make the country more attractive to foreign investors as they enlarge the size of the market in which Costa Rican goods can be sold duty-free.

Unlike many developing countries' foreign investment regime (see, e.g., UNCTAD, 1993), the Costa Rican FDI regime does not contain incentives available only to foreign investors. Some export promotion schemes benefit to a large extent foreign companies but they are also available to domestic firms. This is the case of duty-free trade zones and other very similar schemes presently being implemented in Costa Rica. They offer firms not only tariff exemptions for goods used in production but 
also generous tax holidays. Tax incentives for firms operating in duty-free trade zones in Costa Rica consist of full income tax exemption for 10-12 years, and 50 percent exemption for the following 4-6 years (WTO, 1995). ${ }^{4}$ They also provide full exemption on taxes on capital and assets for an indefinite period of time. Though the main objective of these schemes is export promotion, firms operating in duty-free zones are allowed to sell up to 40 percent of their output in the domestic market (WTO, 1995).

The next Section describes the model used to simulate the effects of unilateral trade liberalization on welfare in Costa Rica, once FDI responses and international capital income taxation are taken into consideration.

\section{The Model}

Production

There are two countries, ${ }^{5} A$ and $B$, each producing $n$ goods $(n>1)$, some of which (at least) are tradeables. Production in each country requires a fixed-proportion combination of value added and intermediate inputs (henceforth superscripts denote

\footnotetext{
${ }^{4}$ The fact that many developed countries use the credit mechanism when taxing foreign source income often makes these income tax incentives largely ineffective when their beneficiaries are foreign companies.

${ }^{5}$ In the empirical implementation of the model we consider in fact three "countries," including a "Rest of the World." To keep notation as simple as possible and avoid repetition, throughout this section we abstract from this third region.
} 
countries, and they refer to $A$ and $B$ unless otherwise indicated; for convenience, subscripts to index sectors are omitted):

$$
X^{i}=\min \left(Q^{i}, Z^{i}\right)
$$

where $X^{i}$ is gross output, $Q^{i}$ is value added and $Z^{i}$ represents intermediate inputs.

Intermediate inputs, in turn, are also required in a fixed proportion:

$$
Z^{i}=\phi^{i} X^{i}
$$

where $\phi^{i}$ denotes the fixed amount of intermediate goods required to produce a unit of output.

Value added requires the use of two primary inputs, labor and capital, $L$ and $K$, whose supply is assumed to be fixed. These primary inputs are combined according to a constant elasticity of substitution (CES) function:

$$
Q^{i}\left(L^{i}, K^{i}\right) \equiv \gamma^{i}\left[\alpha^{i}\left(L^{i}\right)^{\sigma^{i}}+\left(1-\alpha^{i}\right)\left(K^{i}\right)^{\sigma^{i}}\right]^{\frac{1}{\sigma^{i}}}
$$

where $Q^{i}$ denote value added, $\gamma^{i}$ is a shift parameter, $\alpha^{i}$ a share parameters and $\sigma^{i}$ reflects the elasticity of substitution between labor and capital in each country (elasticity, $\left.\epsilon_{1}^{i}=1 /\left(1-\sigma^{i}\right)\right)$.

Furthermore, it is assumed that labor is internationally immobile while capital can move freely across countries. Capital used in production in each country is an aggregate of domestic capital $\left(K_{d}^{i}\right)$ and foreign capital $\left(K_{m}^{i}\right)$, which are viewed as imperfect substitutes. ${ }^{6}$ This specification allows for the consideration of the phenomenon

\footnotetext{
${ }^{6}$ This capital specification has also been used in some models of taxation in open economies (e.g.
} 
of cross-hauling in international capital flows, reflected by balance of payments data. The corresponding aggregate capital function is given by

$$
K^{i}\left(K_{d}^{i}, K_{m}^{i}\right) \equiv\left[\delta^{i}\left(K_{d}^{i}\right)^{\rho^{i}}+\left(1-\delta^{i}\right)\left(K_{m}^{i}\right)^{\rho^{i}}\right]^{\frac{1}{\rho^{i}}}
$$

where $\delta^{i}$ are share parameters and $\rho^{i}$ reflects the elasticity of substitution between domestic and foreign capital in each country (elasticity, $\epsilon_{2}^{i}=1 /\left(1-\rho^{i}\right)$ ).

We assume that both countries tax their capital on a world-wide basis and give a tax credit for taxes paid abroad. The maximum amount of tax credit is the corresponding home country tax liability. Countries are assumed to apply the same tax rate to foreign source and domestically generated income. We denote these rates by $\tau^{A}$ and $\tau^{B}$ and assume that $\tau^{A}>\tau^{B}$. Taxation in each country does not discriminate between income from foreign capital and income from domestic capital generated internally. In each country, the rate of return is in principle different for domestic and foreign capital.

The equilibrium conditions for factor demand are as follows:

For labor,

$$
\omega^{i}=\frac{\partial Q^{i}}{\partial L^{i}}
$$

where $\omega^{i}$ represent the wage rate.

For foreign capital and domestic capital, respectively,

$$
v_{m}^{i}=\left(1-\tau^{A}\right) \frac{\partial Q^{i}}{\partial K^{i}} \frac{\partial K^{i}}{\partial K_{m}^{i}}
$$

Wang and Pereira, 1994). In a dynamic setting, Bovenberg (1986) also uses an specification like this for investment goods. 


$$
v_{d}^{i}=\left(1-\tau^{A}\right) \frac{\partial Q^{i}}{\partial K^{i}} \frac{\partial K^{i}}{\partial K_{d}^{i}} ;
$$

where $v_{m}^{i}$ and $v_{d}^{i}$ represent the net return on foreign and domestic capital in each country.

Equilibrium in the international allocation of capital requires that capital of a given nationality earns the same net return regardless of where is used (domestically or abroad). That is,

$$
\begin{aligned}
& v_{d}^{A}=v_{m}^{B} \\
& v_{d}^{B}=v_{m}^{A}
\end{aligned}
$$

We also assume that there is perfect competition both in goods and factor markets. In the latter, the assumption of full employment is also made.

\section{Consumption and Trade}

Imported and domestic goods, $M^{i}$ and $D^{i}$, respectively, are assumed to be imperfect substitutes for each other. Traded goods consumed in each country are a composite, $Y^{i}$, of $M^{i}$ and $D^{i}$. The corresponding CES aggregation function is given by

$$
Y^{i} \equiv\left[\psi^{i}\left(M^{i}\right)^{-\eta^{i}}+\left(1-\psi^{i}\right)\left(D^{i}\right)^{-\eta^{i}}\right]^{-\frac{1}{\eta^{i}}}
$$

where $\psi^{i}$ is a share parameter and $\eta^{i}$ reflects the elasticities of substitution between domestic and imported goods (elasticity, $\left.\epsilon_{3}^{i}=\left(1-\eta^{i}\right) / \eta^{i}\right)$.

Similarly, for exports we use a Constant Elasticity of Transformation (CET) function. Thus, the technology that transforms output for the domestic market into output for the export market is described by

$$
X^{i} \equiv\left[\beta^{i}\left(D^{i}\right)^{\theta^{i}}+\left(1-\beta^{i}\right)\left(E^{i}\right)^{\theta^{i}}\right]^{\frac{1}{\theta^{i}}}
$$


where $D^{i}$ and $E^{i}$ are output produced for the domestic and export market, respectively, $\beta^{i}$ is a distribution parameter and $\theta^{i}$ reflects the elasticity of transformation (elasticity, $\left.\epsilon_{4}^{i}=\left(1+\theta^{i}\right) / \theta^{i}\right)$.

Countries levy tariffs on their imports at rates $t^{i}$. Thus, the domestic price of imports inclusive of tariffs is

$$
P_{m}^{i}=P_{m}^{w}\left(1+t^{i}\right)
$$

where $P_{m}^{w}$ is the world price of imports.

\section{Income}

It is assumed that revenue from income and trade taxes is returned to consumers in a lump-sum fashion. Thus, assuming also that profits from foreign capital are fully repatriated to the home country once the corresponding domestic income taxes have been paid, augmented income for country $A$ is given by (that for $B$ follows by symmetry)

$$
I^{A}=\omega^{A} L^{A}+r_{d}^{A} K_{d}^{A}+\left(1-\tau^{A}\right) r_{m}^{B} K_{m}^{B}+\tau^{A} r_{m}^{A} K_{m}^{A}+t^{A} P_{m}^{w} M^{A}
$$

where the $r_{d}^{A}$ and $r_{m}^{i}$ are the gross rate of return on domestic and foreign capital, respectively.

\section{Market Clearing Conditions}

Equilibrium in the goods market requires

$$
Y^{i}=D^{i}+M^{i}
$$


In the factor market, the clearing conditions are

$$
\begin{aligned}
& L^{i}=L_{s}^{i} \\
& K^{A}=K_{d}^{A}+K_{m}^{B} \\
& K^{B}=K_{d}^{B}+K_{m}^{A} .
\end{aligned}
$$

where $L_{s}^{i}$ is the exogenous labor supply in each country.

\section{Data and Parameter Calibration}

The model described above has been calibrated to a 1990-91 data set on production, trade and foreign direct investment for the economies of Costa Rica and a group of OECD countries. The latter is made up of those countries which, as of 1991, offered credits for taxes paid by their foreign investors in countries with which they did not have an agreement to avoid international double taxation of capital income. ${ }^{7}$ This suits also the case of Costa Rica, who, as of 1994, had not signed a treaty like that with any of the OECD countries included in our group, except Germany (who, in any case, uses the crediting mechanism with treaty-countries also). These group of countries is responsible for more than 80 percent of FDI in Costa Rica. As mentioned earlier, the empirical implementation of the model also includes a "Rest of the World." OECD countries which do not use the credit mechanism are included in the Rest of the World, together with developing countries.

\footnotetext{
${ }^{7}$ These countries are: Australia, Denmark, Finland, Germany, Greece, Iceland, Italy, Japan, Netherlands, New Zealand, Spain, Sweden, Turkey, United Kingdom and the USA.
} 
The model contains 10 sectors and one household. We have aggregated the primary sector into one basically because of the lack of data on capital flows. In desaggregating the manufacturing sector-whenever data constraints have allowed us-, we have tried to separate those activities which have achieved a relatively high degree of development by Costa Rican standards. The model includes separately a nontradeable sector (some non-traded services and construction) which, in Costa Rica (in 1991), has no international capital flows.

The production and trade-flows data for the Costa Rican economy comes from the Central Bank and the Ministry of Economy of Costa Rica. Sectoral foreign capital stocks in manufacturing have been obtained on the basis of foreign capital shares in overall capital income in each sector. Foreign capital stocks for agriculture and services were obtained from UNCTAD's World Investment Directory 1994. These were combined with estimates of aggregate capital stocks in those sectors to obtain sectoral domestic capital stocks. As no information on taxes paid by foreign companies is available, we assume that no income tax exemptions are given to them, ${ }^{8}$ and that they pay the legal 20 percent rate on their profits.

Table 2 presents the basic data used for the economy of Costa Rica. This is a semi-industrialized economy with a relatively large service sector. Manufacturing activities - especially light industry — have traditionally enjoyed a high tariff protection vis-à-vis agriculture, and have tended to rely more heavily on imports, particu-

\footnotetext{
${ }^{8}$ This is consistent with Costa Rica's FDI regime, though not with its free-duty zone legislation (see Section 3).
} 
larly of intermediate and capital goods.

The share of capital in value added in the Costa Rican economy has traditionally been high, especially in manufacturing, where it exceeds 60 per cent. Capital, however, is overwhelmingly owned by nationals in all sectors of the economy. Compared to some larger Latin American countries, for instance, foreign capital has not played a particularly important role in the economy of Costa Rica. ${ }^{9}$ FDI has tended to concentrate more in manufacturing. The United States is by far the single most important foreign investor in the country, with American companies controlling about a quarter of FDI in the manufacturing sector and virtually all foreign capital in agriculture (UNCTAD, 1994, vol. 4).

Production data, including input-output flows, for the group of OECD countries comes from OECD (1995), and is based on data for Canada, Germany, Japan, the United Kingdom and the USA. Trade flows net of intra-regional trade have been computed from information from OECD's Statistics of Foreign Trade by Commodity 1992 for the same countries. Sectoral foreign capital stocks are based on the share of foreign assets in aggregate assets in each sector for the same group of countries, excluding Canada (for which this information was not available). The data is based on information from UNCTAD (1994). Tariff rates refer to MNF tariffs corrected

\footnotetext{
${ }^{9}$ Indicators on the importance of foreign capital in Latin American countries are usually scant but those existing are quite revealing: In Brazil, in 1990, more than 40 percent of overall profits in the economy were generated by foreign affiliates; while in Mexico, in 1986 - when the Mexican foreign investment regime was still very restrictive - more than half of all assets were controlled by foreign affiliates (UNCTAD, 1994, Vol. 4, Table 9).
} 
Table 2: Costa Rica: Some Central Case Parameters

$\begin{array}{lcccccc} & Q S H & M / Y & E / X & K I / Q & K I_{m} / K I & \text { Tariffs }^{*} \\ \text { Primary sector } & 0.180 & 0.126 & 0.424 & 0.573 & 0.167 & 0.0004 \\ \text { Food. bev. and tob. } & 0.100 & 0.067 & 0.295 & 0.678 & 0.062 & 0.087 \\ \text { Textiles and apparel } & 0.017 & 0.495 & 0.468 & 0.547 & 0.096 & 0.139 \\ \text { Paper and printing } & 0.016 & 0.392 & 0.096 & 0.647 & 0.153 & 0.041 \\ \text { Chemical products } & 0.019 & 0.606 & 0.222 & 0.645 & 0.095 & 0.040 \\ \text { Non-met. mineral prod. } & 0.010 & 0.288 & 0.156 & 0.658 & 0.337 & 0.147 \\ \text { Metal products } & 0.005 & 0.836 & 0.472 & 0.712 & 0.422 & 0.053 \\ \text { Other manufacturing } & 0.034 & 0.582 & 0.275 & 0.686 & 0.111 & 0.069 \\ \text { Tradeable services } & 0.376 & 0.085 & 0.192 & 0.520 & 0.027 & \text { n.a. } \\ \text { Non-tradeables } & 0.244 & 0.000 & 0.000 & 0.275 & 0.000 & \text { n.a. } \\ \text { Overall } & 1.000 & 0.214 & 0.219 & 0.498 & 0.073 & 0.052\end{array}$

Column headings:

QSH: Value added share

$M / Y$ : Share of imports in supply

$E / X$ : Share of exports in output

$K I / Q$ : Share of capital income in value added

$K I_{m} / K I$ : Share of foreign capital income in aggregate capital income

* Ratio of tariff revenue to imports. This column is quite different from those in Table 1 both because it corresponds to a different year (1991) and because takes into account exemptions and the existence of free trade within the CACM.

n.a. $=$ not applicable 
by the coverage of the Generalized System of Preferences (GSP) program in each sector. ${ }^{10}$ For completeness, Table 3 presents some base data for the group of OECD countries.

Regarding elasticities, the trade elasticity values we use are based on those that have recently been used in the literature (see, e.g. Hinojosa-Ojeda and Robinson, 1991; Perroni and Wigle, 1994). We use a lower elasticity value for primary goods as these tend to be more homogeneous across countries than, for instance, manufacturing goods. To take account of country size, smaller elasticities are used for Costa Rica. The values we use are: 1.25 for primary goods and 1.75 for other goods, for Costa Rica; and 2.0 and 2.5, respectively, for the group of OECD countries. As to inputsubstitution in value added, we use a Cobb-Douglas specification. The elasticity of substitution between domestic and foreign capital, in turn, has been assumed to be 1.25 and 2.0 in Costa Rica and the group of OECD countries, respectively, in all sectors. We carry out sensitivity analysis on the values of trade and capital substitution elasticities. Finally, shift and share parameters are obtained through calibration.

\section{Simulation Results}

We have used the model and data described above to quantify the welfare gains, or losses, to the economy of Costa Rica from completely eliminating import tariffs. We also compute the optimal tariff structure for this economy in the presence of taxation

\footnotetext{
${ }^{10}$ We have used the proportion of items within each sector covered by the GSP program in the United States.
} 
Table 3: OECD countries: Some Central Case Parameters

$\begin{array}{lcccccc} & Q S H & M / Y & E / X & K I / Q & K I_{m} / K I & \text { Tariffs } \\ \text { Primary sector } & 0.034 & 0.119 & 0.015 & 0.683 & 0.005 & 0.035 \\ \text { Food. bev. and tob. } & 0.025 & 0.037 & 0.020 & 0.357 & 0.034 & 0.041 \\ \text { Textiles and apparel } & 0.011 & 0.171 & 0.025 & 0.226 & 0.020 & 0.086 \\ \text { Paper and printing } & 0.021 & 0.020 & 0.020 & 0.265 & 0.005 & 0.017 \\ \text { Chemical products } & 0.023 & 0.020 & 0.064 & 0.300 & 0.025 & 0.032 \\ \text { Non-met. mineral prod. } & 0.001 & 0.027 & 0.024 & 0.323 & 0.065 & 0.043 \\ \text { Metal products } & 0.023 & 0.026 & 0.036 & 0.295 & 0.005 & 0.028 \\ \text { Other manufacturing } & 0.112 & 0.046 & 0.077 & 0.206 & 0.005 & 0.031 \\ \text { Tradeable services } & 0.265 & 0.009 & 0.017 & 0.379 & 0.009 & \text { n.a. } \\ \text { Non-tradeables } & 0.479 & 0.000 & 0.000 & 0.445 & 0.000 & \text { n.a. } \\ \text { Overall } & 1.000 & 0.023 & 0.023 & 0.393 & 0.073 & \text { n.a. }\end{array}$

Column headings:

QSH: Value added share

$M / Y$ : Share of imports in supply

$E / X$ : Share of exports in output

$K I / Q$ : Share of capital income in value added

$K I_{m} / K I$ : Share of foreign capital income in aggregate capital income

n.a. $=$ not applicable 
of foreign capital income. Our result discussion focuses on Costa Rica since we are concerned with the case of a small economy. Central case results for this country are presented in Table 4.

Table 4 presents the welfare and capital flow effects of trade liberalization as well as the optimal import-tariff structure. With no taxation of foreign capital income, the optimal commercial policy consists effectively of free trade. Trade liberalization causes an outflow of capital of 0.66 percent, which, in the absence of foreign capital taxation, does not hurt the economy and is in fact accompanied by a slight welfare improvement (the small size of this improvement is the result of relatively low tariffs - which, furthermore, generally do not exhibit a great deal of dispersion, as shown in Table 2). The intuition for capital leaving the country is provided by the Stolper-Samuelson theorem. Since in Costa Rica import-tariff protection is higher for manufacturing activities (Table 2), its elimination tends generally to contract these activities. Given that in this economy manufacturing activities tend to be intensive users of capital relative to others, its contraction reduces the demand for capital, making this factor's return fall.

With foreign capital being taxed, the outflow of capital produced by complete tariff elimination causes welfare to fall by about 0.05 per cent. This results from lower income tax revenue and national income. The small size of the welfare decline suggests that the optimal tariff structure is not very different from free trade - and in fact this turns out to be the case (Table 4). Under the optimal tariff structure with foreign capital taxation, agricultural imports would be subsidized whereas those of manufacturing goods would be generally subject to a tariff. Optimal tariffs tend to 
Table 4: Trade Liberalization Effects and Optimal Tariff Structure:

Central Case

I. Liberalization Effects (\%)

Change

1. Welfare (change in utility)

A. With no foreign capital taxation

0.21

B. With foreign capital taxation

$-0.05$

2. Capital Stock (change in aggregate level)

II. Optimal Tariff Structure (\%)

Tariff Rate

Primary sector

$-4.21$

Food. bev. and tob.

0.12

Textiles and apparel

$-0.21$

Paper and printing

$-0.02$

Chemical products

1.15

Non-met. mineral prod.

2.56

Metal products

3.21

Other manufacturing

Tradeable services

n.a.

Non-tradeables

n.a.

n.a. $=$ not applicable 
be higher in those sectors using capital more intensively, and which have a larger FDI share (metal products and other manufacturing, especially).

The low level of the optimal subsidy and tariff is basically driven by the relatively modest role played by foreign capital in the Costa Rican economy (Table 2). Of some significance is also the fact that trade intervention distorts consumption patterns as well. Substitution elasticities also play a role, though this is not very important in absolute terms (Tables 5 and 6). Furthermore, the pattern of results across sectors remains basically unchanged as elasticity values are varied. Higher trade elasticities imply that trade liberalization has a stronger impact on goods relative prices and thereby on relative factor returns. This leads to free trade causing a larger outflow of capital, which, in turn, generates higher welfare losses when foreign capital is taxed (Table 5). The dispersion of incentives associated with the optimal tariffs is now slightly greater. With a higher degree of substitution between foreign and domestic capital (the corresponding elasticities are now equal to 2.0 for Costa Rica), the capitaloutflow effect of trade liberalization is also strengthened (Table 6). Accordingly, the negative welfare impact under foreign capital taxation is magnified. The level of both the optimal tariff and subsidy increases.

We have also computed the welfare gains for Costa Rica from directly subsidizing capital (the first-best policy) instead of using import tariffs/subsidies. Results (for the central case specification) show that this would increase welfare by only 0.02 percent in comparison with the optimal tariff scenario. This modest gain is not surprising given that the optimal-tariff level across sectors is quite small and does not present a great deal of dispersion (Table 4). Increasing the tax on foreign capital 
Table 5: Trade Liberalization Effects and Optimal Tariff Structure:

Sensitivity Analyses on Trade Elasticities*

I. Liberalization Effects (\%)

Change

1. Welfare (change in utility)

A. With no foreign capital taxation

B. With foreign capital taxation

2. Capital Stock (change in aggregate level)

$-0.68$

II. Optimal Tariff Structure (\%)

Tariff Rate

Primary sector

Food. bev. and tob.

Textiles and apparel

Paper and printing

Chemical products

Non-met. mineral prod.

Metal products

Other manufacturing

tradeable services

n.a.

Non-tradeables

n.a.

* trade elasticities are now 2.0 in agriculture and and 2.5 in other sectors.

n.a. = not applicable 
Table 6: Trade Liberalization Effects and Optimal Tariff Structure: Sensitivity Analyses on Capital Elasticities*

I. Liberalization Effects (\%)

Change

1. Welfare (change in utility)

A. With no foreign capital taxation

B. With foreign capital taxation

2. Capital Stock (change in aggregate level)

$-0.66$

II. Optimal Tariff Structure (\%)

Tariff Rate

Primary sector $-5.01$

Food. bev. and tob. 0.18

Textiles and apparel

Paper and printing $-0.03$

Chemical products 1.75

Non-met. mineral prod. 3.82

Metal products 3.97

Other manufacturing 6.24

tradeable services n.a.

Non-tradeables n.a.

* capital substitution elasticities are now 2.0 in all sectors n.a. $=$ not applicable 
income to a level similar to the OECD average (approximately 38 percent in 1991 for countries using the credit mechanism) would generate greater welfare gains (three times as much) than a switch to a direct subsidy. In a more desaggregated model, this number should be smaller, as our calculation does not take into consideration the fact that companies from countries with a tax rate lower than the OECD average will find themselves with non-refundable excess credits and might therefore prefer to locate in a different country. Despite this, a greater tax rate on foreign capital income might still be a superior option to the direct subsidy and seems to be more feasible as well.

\section{Summary and Conclusion}

This paper has used a calibrated general equilibrium model to quantify the welfare impact of trade liberalization and compute the optimal tariff structure for Costa Rica in the presence of trade-policy-induced capital flows and foreign capital taxation. We find that with foreign capital being taxed and the tax credit system in force, the complete elimination of import tariffs hurts Costa Rica. This to the extent that tariff removal leads to an outflow of capital and a loss of tax revenue that more than offset the positive traditional reallocation effect of moving to free trade. Thus, the optimal tariff structure for the Costa Rican economy does not consist of zero-import tariffs, but rather of a mixture of positive import tariffs and subsidies. The optimal tariff and subsidy levels are, however, quite low, reflecting basically the fact that the role of foreign capital in this economy is relatively modest. It would be interesting to examine how results change in an economy in which foreign investment plays a substantially more significant role. 
Given the relatively small level of optimal tariffs/subsidies, and the fact that there seems to exist some costs associated with non-uniform-tariff structures (such as rent-seeking-related costs, for instance), our finding cannot be taken as providing a strong case against free trade in an economy such as the Costa Rican. Also, it must be bear in mind that the (static) nature of our model is unable to capture dynamic gains often associated with trade (Stokey, 1991; Young, 1991). At the same time, it should be noted that even if we restrict our analysis to the static cost and benefits of freer trade, trade liberalization typically does not consist of a complete tariff elimination, but rather of a reduction in the level of protection and its dispersion. Therefore, even in the presence of foreign capital taxation, trade liberalization, as usually practiced, could still yield static welfare gains for a small open economy. Our numerical simulations imply, however, that allowing for capital flows and their taxation might reduce the size of static gains from non-full trade liberalization.

\section{References}

Bhagwati, J. (1973), "The Theory of Immiserizing Growth: Further Applications," in Michael B. Conolly and Alexander K. Swoboda (eds.), International Trade and Money. Toronto: University of Toronto Press.

Bond, E.W. (1991), "Optimal Tax and Tariff Policies with Credits," Journal of International Economics 30: 317-29.

Bovenberg, L. (1986), "Capital Income Taxation in Growing Open Economies," Journal of Public Economics 31: 347-76. 
Brecher, R.A. and C.F. Diaz-Alejandro (1977), "Tariff, Foreign Capital and Immiserizing Growth," Journal of International Economics 7: 317-22

Brecher, R.A. and Findlay, R. (1983), "Tariff, Foreign Capital and National Advantage with Sector-Specific Factors," Journal of International Economics 14: 277-88.

Brown, D. (1992), "The Impact of a North American Free Trade Area: Applied General Equilibrium Models," in N. Lustig, B. Bosworth and R. Z. Lawrence (eds.), North American Free Trade: Assessing the Impact. Washington: The Brookings Institution.

Damus, S., P.A.R. Hobson and W.R. Thirsk (1991), "Foreign Tax Credits, the Supply of Foreign Capital, and Tax Exporting," Journal of Public Economics 45: 29-46.

Francois, J. and C. Shiells, eds. (1994), Modelling Trade Policy: Applied General Equilibrium Assessment of North American Free Trade. New York: Cambridge University Press.

Minabe, N. (1974), "Capital and Technology Movements and Economic Welfare,". American Economic Review 84: 1088-1100.

L. Goulder and B. Eichengreen (1992), "Trade Liberalization in General Equilibrium: Intertemporal and Inter-industry Effects," Canadian Journal of Economics 25: 252-80.

Hinojosa-Ojeda, R. and S. Robinson (1991), "Alternative Scenarios of US-Mexico Integration: A Computable General Equilibrium Approach." Working Paper No. 609 (Department of Agriculture and Resource Economics, University of California, Berkeley).

Jones, R. (1967), "International Capital Movements and the Theory of Tariff and Trade," Quarterly Journal of Economics 81: 1-38.

- (1984), "Protection and the Harmful Effects of Endogenous Capital Flows," Economics Letters 15: 325-30. 
Johnson, H. (1967), "The Possibility of Income Losses from Increased Efficiency or Factor Accumulation in the Presence of Tariffs," Economic Journal 77: 151-54.

Markusen, J. (1983), "Factor Movements and Commodity Trade as Complements," Journal of International Economics 13: 341-56.

Mundell, R. (1957), "International Trade and Factor Mobility," American Economic Review 47: 321-35.

Nathan and Associates (1994), "Leyes de Inversion Extranjera y Zonas Francas en Centroamerica." San Salvador: US AID (mimeo).

Neary, P. and F. Ruane (1988), "International Capital Mobility, Shadow Prices, and the Cost of Protection," International Economic Review 29: 571-85.

Perroni, C. and R.M. Wigle (1994), "International Trade and Environmental Quality: How Important Are the Linkages," Canadian Journal of Economics 27(3), 55167.

Ruffin, R.J. (1984), "International Factor Movements," in P. Kenen and R. Jones (eds.), Handbook of International Economics, Vol. 1. Amsterdam: NorthHolland.

Schmitz A. and P. Helmberger (1970), "Factor Mobility and International Trade: The Case of Complementarity," American Economic Review 60: 761-767.

Secretaria de la Integracion Economica Centroamericana (SIECA) (1993), Arancel Centroamericano de Importacion. Sistema Arancelario Centroamericano. Guatemala: SIECA.

Stokey, N. (1991), "The Volume and Composition of Trade between Rich and Poor Countries." Review of Economic Studies 58: 63-80.

UNCTAD (1993), World Investment Report. New York: United Nations.

UNCTAD (1994), World Investment Directory. New York: United Nations. 
Young, A. (1991), "Learning by Doing and the Dynamic Effects of International Trade." Quarterly Journal of Economics 106: 369-406.

Wang, L. and A. Pereira (1994), "Capital Income Taxation and International Investment," Public Finance 49: 460-84.

Wong, K. (1986), "Are International Trade and Factor Mobility Substitutes?" Journal of International Economics 21: 25-43.

- (1995), International Trade in Goods and Factor Mobility. Cambridge, Mass: The MIT Press.

World Trade Organization (1995), Trade Policy Review. Costa Rica, 1995. Geneva: WTO. 